\title{
The Effect of Aflibercept and Ranibizumab in Patients with Diabetic Macular Edema: A comparative Study
}

\author{
Abdallah H. Hamed, Ahmad E. Hudieb, Mohamed A. Eid* \\ Department of Ophthalmology, Faculty of Medicine, Al-Azhar University \\ *Corresponding author: Mohamed A. Eid; Mobile: 01005748110; Email: drmohamedeidopth@ gmail.com
}

\begin{abstract}
Background: Diabetic macular edema is one of the most significant causes of blindness and severe visual impairment in patients with diabetes, which can result in reduced quality of life. Three commonly used intravitreous VEGF inhibitors aflibercept, bevacizumab and ranibizumab have been shown to be beneficial and relatively safe for the treatment of diabetic macular edema, but only aflibercept and ranibizumab are approved by the Food and Drug Administration (FDA) for this indication. Aim of the Work: To compare between the effect of ranibizumab and aflibercept in patients with diabetic macular edema as a diabetic retinopathy complication that leads to visual impairment. Patients and Methods: A prospective study of 20 patients (20 eyes) was conducted in Al-Mouneer diabetic eye center with three times injection one month apart. The patients were divided into two groups, Group A was consisted of 10 patients who received ranibizumab as $0.5 \mathrm{mg}(0.05 \mathrm{ml}$ of $10 \mathrm{mg} / \mathrm{ml}$ solution) an intra vitreal injection. Group B was consisted of 10 patients who received aflibercept $2 \mathrm{mg}(0.05 \mathrm{~mL}$ of $40 \mathrm{mg} / \mathrm{ml}$ solution $)$ as an intra vitreal injection with follow up for three months. Results: A statistically significant difference over the time through BCVA and central macular thickness with ranibizumab. There was also a statistically significant difference over the time through BCVA, central macular thickness and IOP with aflibercept. Conclusion: There was more improvement in BCVA which was significant and more reduction in central macular thickness with ranibizumab than with aflibercept. Recommendations: Larger group studies to confirm our results; longer term study for the effect of ranibizumab and aflibercept injection on the central macular thickness and IOP and comparing the effect of single injection versus multiple injections. Searching for the causes of resistance or delayed response to the intravitreal injections in some patients.
\end{abstract}

Key words: Diabetic macular edema, Aflibercept, Ranibizumab

\section{INTRODUCTION}

The alarming rise in diabetes prevalence is a global public health and economic problem. Diabetic retinopathy is the most common complication of diabetes and the leading cause of blindness among working-age populations in the developed world ${ }^{(1)}$.

The worldwide prevalence of DM is predicted to grow to 430 million patients by 2030 , and every one of them will be at risk of developing diabetic retinopathy ${ }^{(2)}$.

The prevalence of diabetic retinopathy (DR) remains high at $40 \%$ of diabetic patients. Globally, there are approximately 93 million people with DR, 70 million with proliferative diabetic retinopathy (PDR), 21 million with diabetic macular edema (DME) and 28 million with a sight- threatening retinopathy as proliferative diabetic retinopathy (PDR) ${ }^{(3)}$.

Diabetic retinopathy (DR) is a microangiopathy characterized by microaneurysms (Mas), capillary nonperfusion, and ischemia within the retina. It may cause several complications, such as diabetic macular edema (DME) and diabetic macular ischemia (DMI). In particular, capillary non perfusion impairs the nutrition of the neuroglial tissues in the retinal parenchyma, and the resultant hypoxia increases the expression of vascular endothelial growth factor (VEGF), which promotes both angiogenic responses and vascular permeability ${ }^{(5)}$.

The classic retinal lesions of DR include microaneurysms, hemorrhages, venous beading (venous caliber changes consisting of alternating areas of venous dilation and constriction), intraretinal-microvascular abnormalities, hard exudates (lipid deposits), cottonwool spots (ischemic retina leading to accumulations of axoplasmic debris within adjacent bundles of ganglion cell axons), and retinal neovascularization. These findings can be utilized to classify eyes as having one of two phases of DR ${ }^{(6)}$ :

\section{Non proliferative Diabetic Retinopathy (NPDR)}

Eyes progress from having no DR through a spectrum of DR severity that includes mild, moderate and severe NPDR. Correct identification of the DR severity level of an eye allows a prediction of risk of DR progression, visual loss, and determination of appropriate treatment recommendations including follow-up interval ${ }^{(7)}$.

\section{Proliferative Diabetic Retinopathy (PDR)}

Proliferative diabetic retinopathy (PDR) is the most advanced stage of DR and represents an angiogenic response of the retina to extensive ischemia from capillary closure. Retinal neovascularization is typically characterized as being new vessels on the disc (NVD) or new vessels elsewhere (NVE) along the vascular arcades ${ }^{(7)}$.

Diabetic macular edema, a manifestation of diabetic retinopathy that impairs central vision, affects approximately 750,000 people in the United States and is a leading cause of vision loss. The costs associated with visual disability and treatment of 
diabetic macular edema are high. The increasing prevalence of diabetes worldwide highlights the importance of diabetic macular edema as a global health issue ${ }^{(8)}$.

The Early Treatment Diabetic Retinopathy Study (ETDRS) defined macular edema as thickening of the retina and/or hard exudates within one disc diameter of the center of the macula ${ }^{(9)}$.

Alteration of the blood-retinal barrier is the hallmark of this disease, characterized by pericyte loss and endothelial cell-cell junction breakdown. Recent animal and clinical studies strongly indicate that DME is an inflammatory disease. Multiple cytokines and chemokines are involved in the pathogenesis of DME, with multiple cellular involvement affecting the neurovascular unit ${ }^{(10)}$.

Risk factors that contribute to the progression of DME include increasing levels of hyperglycemia, diabetes duration, severity of diabetic retinopathy at baseline, diastolic blood pressure and the presence of gross proteinuria ${ }^{(11)}$.

The common diagnostic tools for assessing macular edema are stereo- ophthalmoscopy and fluorescein angiography. Stereoscopic examination of the fundus at the slit-lamp or on stereoscopic color fundus photographs is the standard method, as defined by the Early Treatment Diabetic Retinopathy Study (ETDRS), for evaluating macular thickening and for starting treatment when the clinical significant macular edema level has been reached ${ }^{(12)}$.

Optical Coherence Tomography (OCT) is a high resolution, cross- sectional imaging technique that allows detailed assessment of retinal thickness and morphologic evaluation of the neurosensory retinal layers. OCT imaging has been integrated into diagnosis and management of DME in routine clinical practice and clinical trials ${ }^{(13)}$.

Diabetic macular edema (DME) is recently classified into a central involved and non central involved macular edema. Central involved macular edema is defined as retinal thickening in the macula that involves the central subfield zone that is $1 \mathrm{~mm}$ in diameter ${ }^{(7)}$.

Vascular Endothelial growth factor (VEGF) levels are elevated in the retina and vitreous of eyes with diabetic retinopathy ${ }^{(14)}$.

Intravitreous injections of anti-VEGF agents have been shown to be the standard treatment for diabetic macular edema since the 1980s. In 2013, an estimated $90 \%$ of retinal specialists in the United States reported using anti-VEGF therapy for initial management of vision loss from diabetic macular edema involving the macular center ${ }^{(2)}$.

Three commonly used intravitreous VEGF inhibitors - aflibercept, bevacizumab and ranibizumab - have been shown to be beneficial and relatively safe for the treatment of diabetic macular edema, but only aflibercept and ranibizumab are approved by the Food and Drug Administration (FDA) for this indication. Bevacizumab, which is not approved by the FDA for any ocular indication, is widely used for off-label treatment of diabetic macular edema in repackaged aliquots containing approximately 1/500th of the systemic dose used in cancer therapy ${ }^{(15)}$.

\section{Aim of the Work}

To compare between the effect of ranibizumab and aflibercept in patients with diabetic macular edema which is one of the most common complications of diabetic retinopathy that leads to visual impairment.

\section{Patients and Methods}

A prospective study of 20 patients (20 eyes) was conducted in Al-Mouneer Diabetic Eye Center with three times injection one month apart. The patients were divided into two groups, Group A was consisted of 10 patients who received ranibizumab as $0.5 \mathrm{mg}(0.05 \mathrm{ml}$ of $10 \mathrm{mg} / \mathrm{ml}$ solution $)$ an intra vitreal injection. Group B was consisted of 10 patients who received aflibercept $2 \mathrm{mg}(0.05 \mathrm{~mL}$ of $40 \mathrm{mg} / \mathrm{ml}$ solution) as an intra vitreal injection with follow up for three months.

\section{Inclusion Criteria:}

Patients with diabetic macular edema who need an intra vitreal injection of Anti VGEF with no other factors mentioned in the exclusion criteria.

Exclusion Criteria: Patients with macular edema due to other medical causes like retinal vein occlusion (RVO), choroidal neovascularization (C.N.V.),... etc. Patients with postoperative macular edema after phaco emulsification (Irvine Gass syndrome). Patients with past history of trauma, uveitis, glaucoma and retinal dystrophies.

All patients were subjected to: Visual acuity, unaided and aided. Slit lamp biomicroscopy for evaluation of anterior segment. Measuring intra ocular pressure using air puff tonometer. Indirect ophthalmoscopy to assess media clarity and retinal pathology. Fundus Fluorescein Angiography (F.F.A.) was done for all patients using Topcon device pre operative and after the third injection. Optical Coherence Tomography (OCT) examination was done for all patients using Topcon 3D OCT 2000 preoperative and follow up OCT every month for three months after each injection.

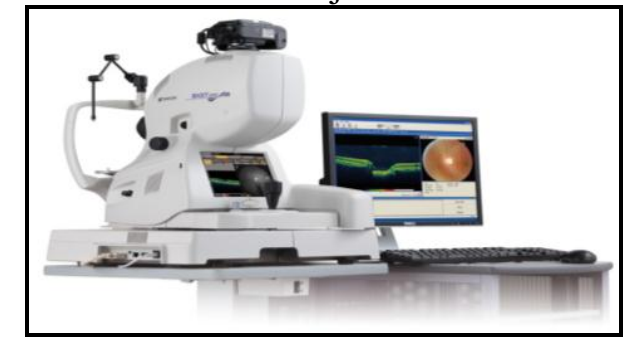

Figure (1): Topcon 3D OCT device. 

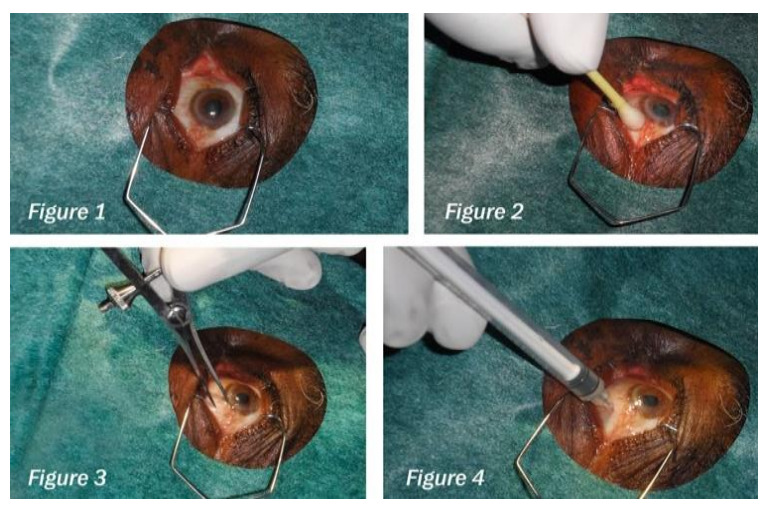

Figure (2): Illustration of intra vitreal injection.

Ethical considerations: This prospective study was conducted, in accordance with the ethical standards stated in the faculty of Medicine - Al-Azhar University. Informed consent taken from all patients before surgery.

Statistical analysis: Recorded data were analyzed using the statistical package for social sciences, version 20.0 (SPSS Inc., Chicago, Illinois, USA). Quantitative data were expressed as mean \pm standard deviation (SD). Qualitative data were expressed as frequency and percentage.

The following tests were done: Independent-samples t-test of significance was used when comparing between two means. A one-way analysis of variance (ANOVA) when comparing between more than two means. Chi-square (X2) test of significance was used in order to compare proportions between two qualitative parameters. The confidence interval was set to $95 \%$ and the margin of error accepted was set to $5 \%$. So, the p-value was considered significant as the following: Probability (P-value): $\mathrm{P}$-value $<0.05$ was considered significant. $\mathrm{P}$-value $<0.001$ was considered as highly significant. $\mathrm{P}$-value $>0.05$ was considered insignificant.

\section{RESULTS}

Table (1): Comparison between groups according to demographic data

\begin{tabular}{|c|c|c|c|c|}
\hline Demographic Data & $\begin{array}{c}\text { Group I } \\
\text { (Ranibizumab) } \\
(\mathbf{N}=7)\end{array}$ & $\begin{array}{c}\text { Group II } \\
\text { (Aflibercept) } \\
(\mathrm{N}=6)\end{array}$ & $t / x 2 \#$ & p-value \\
\hline $\begin{array}{l}\text { Age (years) } \\
\text { Mean } \pm \text { SD } \\
\text { Range } \\
\end{array}$ & $\begin{array}{c}50.14 \pm 11.32 \\
38-64\end{array}$ & $\begin{array}{c}57.17 \pm 11.30 \\
40-71 \\
\end{array}$ & 1.245 & 0.288 \\
\hline $\begin{array}{l}\text { Sex } \\
\text { Female } \\
\text { Male }\end{array}$ & $\begin{array}{l}6(85.7 \%) \\
1(14.3 \%)\end{array}$ & $\begin{array}{l}2(33.3 \%) \\
4(66.7 \%)\end{array}$ & 3.943\# & 0.139 \\
\hline $\begin{array}{l}\text { Eye } \\
\text { Unilateral } \\
\text { Bilateral }\end{array}$ & $\begin{array}{l}4(57.1 \%) \\
3(42.9 \%)\end{array}$ & $\begin{array}{l}2(28.6 \%) \\
4(57.1 \%)\end{array}$ & $0.202 \#$ & 0.654 \\
\hline
\end{tabular}

This table shows no statistically significant difference between groups according to demographic data.
Table (2): Comparison between groups according to BCVA, central thickness and IOP before injection.

\begin{tabular}{||c|c|c|c|c||}
\hline $\begin{array}{c}\text { Before } \\
\text { injection }\end{array}$ & $\begin{array}{c}\text { Group I } \\
\text { (Ranibizumab) } \\
(\mathbf{N}=\mathbf{1 0})\end{array}$ & $\begin{array}{c}\text { Group II } \\
\text { (Aflibercept) } \\
(\mathbf{N}=\mathbf{1 0})\end{array}$ & t-test & p-value \\
\hline \hline $\begin{array}{c}\text { BCVA } \\
\text { Mean } \pm \text { SD } \\
\text { Range }\end{array}$ & $\begin{array}{c}0.71 \pm 0.14 \\
0.5-1\end{array}$ & $\begin{array}{c}0.54 \pm 0.32 \\
0.1-1\end{array}$ & 2.473 & 0.133 \\
\hline $\begin{array}{c}\text { Central } \\
\text { thickness }\end{array}$ & & & & \\
$\begin{array}{c}\text { Mean } \pm S D \\
\text { Range }\end{array}$ & $\begin{array}{c}344.80 \pm 131.56 \\
209-592\end{array}$ & $\begin{array}{c}288.70 \pm 65.69 \\
218-458\end{array}$ & 1.455 & 0.243 \\
\hline $\begin{array}{c}\text { IOP } \\
\text { Mean } \pm S D \\
\text { Range }\end{array}$ & $\begin{array}{c}15.60 \pm 1.65 \\
13-18\end{array}$ & $\begin{array}{c}16.40 \pm 3.37 \\
11-22\end{array}$ & 0.454 & 0.509 \\
\hline
\end{tabular}

This table shows no statistically significant difference between groups according to BCVA, central thickness and IOP before injection.

Table (3): Comparison between groups according to BCVA, central thickness and IOP after 1st injection.

\begin{tabular}{|c|c|c|c|c|}
\hline $\begin{array}{l}\text { After 1st } \\
\text { Injection }\end{array}$ & $\begin{array}{l}\text { Group I } \\
\text { (Ranibizumab) } \\
(\mathrm{N}=7)\end{array}$ & $\begin{array}{l}\text { Group II } \\
\text { (Aflibercept) } \\
(\mathrm{N}=6)\end{array}$ & t-test & p-value \\
\hline $\begin{array}{l}\text { BCVA } \\
\text { Mean } \pm \text { SD } \\
\text { Range } \\
\end{array}$ & $\begin{array}{l}0.84 \pm 0.10 \\
0.7-1\end{array}$ & $\begin{array}{l}0.60 \pm 0.32 \\
0.1-1\end{array}$ & 5.163 & 0.036 \\
\hline $\begin{array}{l}\text { Central } \\
\text { thickness } \\
\text { Mean } \pm \text { SD } \\
\text { Range }\end{array}$ & $\begin{array}{l}254.20 \pm 44.63 \\
200-318\end{array}$ & $\begin{array}{l}244.80 \pm 40.44 \\
187-294\end{array}$ & 0.244 & 0.628 \\
\hline $\begin{array}{l}\text { IOP } \\
\text { Mean } \pm \text { SD } \\
\text { Range }\end{array}$ & $\begin{array}{l}15.70 \pm 1.89 \\
13-18\end{array}$ & $\begin{array}{l}15.30 \pm 3.23 \\
10-21\end{array}$ & 0.114 & 0.739 \\
\hline
\end{tabular}

This table shows statistically significant difference between groups according to BCVA after 1 st injection.

Table (4): Comparison between groups according to BCVA, central thickness and IOP after 2nd injection.

\begin{tabular}{|c|c|c|c|c|}
\hline $\begin{array}{l}\text { After } \\
\text { Injection }\end{array}$ & $\begin{array}{l}\text { Group I } \\
\text { (Ranibizumab) } \\
(\mathrm{N}=7)\end{array}$ & $\begin{array}{l}\text { Group II } \\
\text { (Aflibercept) } \\
(\mathrm{N}=6)\end{array}$ & t-test & $\begin{array}{l}\mathrm{p}- \\
\text { value }\end{array}$ \\
\hline $\begin{array}{l}\text { BCVA } \\
\text { Mean } \pm \text { SD } \\
\text { Range }\end{array}$ & $\begin{array}{l}0.87 \pm 0.09 \\
0.7-1\end{array}$ & $\begin{array}{l}0.61 \pm 0.31 \\
0.1-1\end{array}$ & 6.404 & 0.021 \\
\hline $\begin{array}{l}\text { Central thickness } \\
\text { Mean } \pm \text { SD } \\
\text { Range }\end{array}$ & $\begin{array}{l}229.90 \pm 40.88 \\
191-316\end{array}$ & $\begin{array}{l}235.40 \pm 38.20 \\
180-284\end{array}$ & 0.097 & 0.759 \\
\hline $\begin{array}{l}\text { IOP } \\
\text { Mean } \pm \text { SD } \\
\text { Range }\end{array}$ & $\begin{array}{l}16.20 \pm 2.30 \\
14-20\end{array}$ & $\begin{array}{l}15.00 \pm 2.94 \\
11-19\end{array}$ & 1.032 & 0.323 \\
\hline
\end{tabular}

This table shows statistically significant difference between groups according to BCVA after 2nd injection.

Table (5): Comparison between groups according to BCVA, central thickness and IOP after 3rd injection.

\begin{tabular}{|c|c|c|c|c|}
\hline $\begin{array}{l}\text { After 3rd } \\
\text { Injection }\end{array}$ & $\begin{array}{c}\text { Group I } \\
\text { (Ranibizumab) } \\
(\mathrm{N}=7)\end{array}$ & $\begin{array}{c}\text { Group II } \\
\text { (Aflibercept) } \\
(\mathrm{N}=6)\end{array}$ & t-test & $\begin{array}{c}\mathrm{p}- \\
\text { value }\end{array}$ \\
\hline $\begin{array}{l}\text { BCVA } \\
\text { Mean } \pm \text { SD } \\
\text { Range }\end{array}$ & $\begin{array}{c}0.91 \pm 0.12 \\
0.7-1\end{array}$ & $\begin{array}{c}0.64 \pm 0.34 \\
0.1-1\end{array}$ & 5.500 & 0.031 \\
\hline $\begin{array}{l}\text { Central thickness } \\
\text { Mean } \pm \text { SD } \\
\text { Range }\end{array}$ & $\begin{array}{c}226.50 \pm 39.64 \\
182-311\end{array}$ & $\begin{array}{c}231.20 \pm 36.08 \\
176-284\end{array}$ & 0.077 & 0.785 \\
\hline $\begin{array}{l}\text { IOP } \\
\text { Mean } \pm \text { SD } \\
\text { Range }\end{array}$ & $\begin{array}{c}16.20 \pm 3.12 \\
13-22\end{array}$ & $\begin{array}{c}15.00 \pm 2.58 \\
12-19\end{array}$ & 0.878 & 0.361 \\
\hline
\end{tabular}


This table shows statistically significant difference between groups according to BCVA after 3rd injection.

Table (6): The extent of the difference over the periods through BCVA, central thickness and IOP the group I

\begin{tabular}{|c|c|c|c|c|c|c|}
\hline $\begin{array}{c}\text { Group I } \\
\text { (Ranibizumab) } \\
(\mathrm{N}=10)\end{array}$ & $\begin{array}{c}\text { Before } \\
\text { injection } \\
(\mathrm{N}=10)\end{array}$ & $\begin{array}{c}\text { After 1st } \\
\text { Injection } \\
(\mathbf{N}=10)\end{array}$ & $\begin{array}{c}\text { After 2nd } \\
\text { Injection } \\
(\mathrm{N}=10)\end{array}$ & $\begin{array}{c}\text { After 3rd } \\
\text { Injection } \\
(\mathbf{N}=10)\end{array}$ & ANOVA & $\begin{array}{c}\mathbf{p}- \\
\text { value }\end{array}$ \\
\hline $\begin{array}{c}\text { BCVA } \\
\text { Mean } \pm \text { SD } \\
\text { Range }\end{array}$ & $\begin{array}{c}0.71 \pm 0.14 \\
0.5-1\end{array}$ & $\begin{array}{c}0.84 \pm 0.10 \\
0.7-1\end{array}$ & $\begin{array}{c}0.87 \pm 0.09 \\
0.7-1\end{array}$ & $\begin{array}{c}0.91 \pm 0.12 \\
0.7-1\end{array}$ & -3.873 & 0.004 \\
\hline $\begin{array}{c}\text { Central } \\
\text { thickness } \\
\text { Mean } \pm S D \\
\text { Range }\end{array}$ & $\begin{array}{c}344.80 \pm 131.56 \\
209-592\end{array}$ & \begin{tabular}{|c|}
$254.20 \pm 44.63$ \\
$200-318$
\end{tabular} & $\begin{array}{c}229.90 \pm 40.88 \\
191-316\end{array}$ & $\begin{array}{c}226.50 \pm 39.64 \\
182-311\end{array}$ & 2.987 & 0.015 \\
\hline $\begin{array}{c}\text { IOP } \\
\text { Mean } \pm \text { SD } \\
\text { Range }\end{array}$ & $\begin{array}{c}15.60 \pm 1.65 \\
13-18\end{array}$ & $\begin{array}{c}15.70 \pm 1.89 \\
13-18\end{array}$ & $\begin{array}{c}16.20 \pm 2.30 \\
14-20\end{array}$ & $\begin{array}{c}16.20 \pm 3.12 \\
13-22\end{array}$ & -0.943 & 0.370 \\
\hline
\end{tabular}

This table shows statistically significant difference over the periods through BCVA and central thickness in group I.

Table (7): The extent of the difference over the periods through BCVA, central thickness and IOP in the group II.

\begin{tabular}{|c|c|c|c|c|c|c|}
\hline \begin{tabular}{|c|} 
Group II \\
(Aflibercept) \\
(N=10)
\end{tabular} & $\begin{array}{c}\text { Before injection } \\
(\mathrm{N}=10)\end{array}$ & $\begin{array}{c}\text { After 1st } \\
\text { Injection (N=10) }\end{array}$ & $\begin{array}{c}\text { After 2nd } \\
\text { Injection (N=10) }\end{array}$ & $\begin{array}{c}\text { After 3rd } \\
\text { Injection (N=10) }\end{array}$ & ANOVA & p-valuc \\
\hline \begin{tabular}{|l} 
BCVA \\
Mean $\pm S D$ \\
Range
\end{tabular} & $\begin{array}{c}0.54 \pm 0.32 \\
0.1-1\end{array}$ & $\begin{array}{c}0.60 \pm 0.32 \\
0.1-1\end{array}$ & $\begin{array}{c}0.61 \pm 0.31 \\
0.1-1\end{array}$ & $\begin{array}{c}0.64 \pm 0.34 \\
0.1-1\end{array}$ & -2.623 & 0.028 \\
\hline $\begin{array}{l}\text { Central } \\
\text { thickness } \\
\text { Mean } \pm S D \\
\text { Range }\end{array}$ & $\begin{array}{c}288.70 \pm 65.69 \\
218-458\end{array}$ & $\begin{array}{c}244.80 \pm 40.44 \\
187-294\end{array}$ & $\begin{array}{c}235.40 \pm 38.20 \\
180-284\end{array}$ & $\begin{array}{c}231.20 \pm 36.08 \\
176-284\end{array}$ & 2.646 & 0.027 \\
\hline \begin{tabular}{|l|} 
MeP \\
Mean \pm RD \\
Range \\
\end{tabular} & $\begin{array}{c}16.40 \pm 3.37 \\
11-22 \\
\end{array}$ & $\begin{array}{c}15.30 \pm 3.23 \\
10-21\end{array}$ & $\begin{array}{c}15.00 \pm 2.94 \\
11-19 \\
\end{array}$ & $\begin{array}{c}15.00 \pm 2.58 \\
12-19\end{array}$ & 2.492 & 0.034 \\
\hline
\end{tabular}

This table shows statistically significant difference over the periods through BCVA, central thickness, IOP in group II.

\section{DISCUSSION}

Diabetic macular edema is a well-documented, sight threatening complication of DM, Previously described methods of assessing DME include contact and noncontact slit-lamp bio microscopy, indirect fundosocopy, fluorescein angiography, and fundus stereo-photograph ${ }^{(12)}$.

With regard to the socioeconomic burden of the disease, DME can lead to visual impairment (VI) with consequent reduction in quality of life and patients with DME consume significantly more healthcare resources than diabetic patients without retinal complications ${ }^{(16)}$.

The etiology of DME is complex and has not been fully elucidated. Chronic hyperglycemia, the accumulation of oxygen free radicals and advanced glycation end products, and high cholesterol levels have all been implicated as risk factors for the development of $\mathrm{DME}^{(17)}$.

The introduction of OCT allows further objective evaluation of DME. In addition, OCT produces cross-sectional images of the retina that have been found to correlate well with retinal histology as demonstrated by light microscopy ${ }^{(12)}$.

Vascular endothelial growth factor (VEGF)-A has been identified as a key vascular permeability factor that contributes to neovascularization and BRB dysfunction, making it an attractive target for pharmaceutical intervention ${ }^{(18)}$.
Strict blood glucose, lipid and blood pressure control is critical for prevention and treatment of DME. According to the recommendations of the American Diabetes Association, HbA1C should be controlled at 6.5-7\% and blood pressure should be below 130/85 $\mathrm{mmHg}$, with total lipids lower than $100 \mathrm{mg} / \mathrm{dL}$. The purpose of local eye treatment is to reduce swelling, control the progression of the disease, and improve vision. Local treatments for eyes with DME include laser photocoagulation, vitrectomy surgery, and intravitreal injection of drugs ${ }^{(19)}$.

In this comparative-effectiveness, randomized clinical trial of diabetic macular edema causing decreased visual acuity, treatment with intravitreal aflibercept and ranibizumab was associated with a substantial improvement in mean visual acuity by 1 month, with the improvement sustained through three months with the use of a standardized retreatment protocol. On average, greater improvement was seen with ranibizumab than with the other agent.

On correlating between age and sex of patients with the effect of anti VEGF on the BCVA and the central thickness, there was no statistically significant difference.

There was a significant improvement in the visual-acuity after one month of ranibizumab injection (13\%) with much decrease in the central thickness. After the second injection of ranibizumab there was also a significant improvement of BCVA comparing to aflibercept but it was much less than the first one (3\%). The increase in the BCVA (4\%) was also significant after the third injection of ranibizumab comparing to the other agent and more than the second one.

To evaluate the long term efficacy of ranibizumabthe Schmidt-Erfurth et al. ${ }^{(20)}$ was done and showedthatthe patients initially treated with ranibizumab showed a considerable improvement at month 12 in BCVA compared with those treated with laser alone in the core phase. During the extension study, patients in the prior ranibizumab groups were able to maintain the initial BCVA gains achieved at month 12 to months 24 and 36 with individualized ranibizumab treatment.

As regard the effect of ranibizumab on the central thickness, the central subfield thickness decreasedfrom $344.80 \mu \mathrm{m}$ to a level of $254.20 \mu \mathrm{m}$, on average, by $90.6 \pm 86 \mu \mathrm{m}$ after the first injection while it decreased to a level of $229.90 \mu \mathrm{m}$, on average, by $45.7 \pm 4 \mu \mathrm{m}$ after the second injection. The third injection had the least effect on the central thickness comparing to the previous two injections ascentral subfield thickness decreased to a level of $226.50 \mu \mathrm{m}$, on average, by $3.4 \pm 1 \mu \mathrm{m}$.

In Ozturk et al. ${ }^{(21)} 29$ eyes were enrolled in their study in which the ranibizumab treatment increased the median BCVA from 53 to 66 ETDRS letters and decreased the median CSMT from $428 \mu \mathrm{m}$ to 
a level of $279 \mu \mathrm{m}$ after one month of injection, which was statistically significant.

In patients treated with ranibizumab in the Schmidt-Erfurth et al. ${ }^{(20)}$, the mean CRST reductions observed at the end of the core study $(127.8 \mu \mathrm{m}$ at month 12) were maintained at month $36(142.1 \mu \mathrm{m})$.

As regard the effect of aflibercept on the central thickness, the central subfield thickness decreased from $288.70 \mu \mathrm{m}$ to a level of $244.80 \mu \mathrm{m}$, on average, by $43.9 \pm 25 \mu \mathrm{m}$ after the first injection while it decreased to a level of $235.40 \mu \mathrm{m}$, on average, by $9.4 \pm 2 \mu \mathrm{m}$ after the second injection. The third injection had the least effect on the central thickness comparing to the previous two injections as central subfield thickness decreased to a level of $231.20 \mu \mathrm{m}$, on average, by $4.2 \pm 2 \mu \mathrm{m}$. The improvement in the central thickness was significant over the time.

In protocol $\mathrm{T}$, the central subfield thickness decreased at the 1-year visit, on average, by $169 \pm 138$ $\mu \mathrm{m}$ with aflibercept and $147 \pm 134 \mu \mathrm{m}$ with ranibizumab; the thickness was less than $250 \mu \mathrm{m}$ in 135 of 205 eyes (66\%) and 116 of 201 eyes (58\%), respectively. The relative treatment effect on central subfield thickness varied according to initial visual acuity.

Different to previous studies, our study showed more improvement in BCVA $(\mathrm{p}=0.03)$ which is significant and more reduction in central macular thickness with ranibizumab than with aflibercept in accordance withthe study of cost-effectiveness of ranibizumab versus aflibercept in the treatment of visual impairment due to diabetic macular edema done by the UK National Institute for Health and Care Excellence (NICE) ${ }^{(22)}$ in which ranibizumab was dominant over aflibercept, by demonstrating lower life time costs for UK healthcare providers as well as higher gains for patients receiving ranibizumab than for those taking aflibercept. The main drivers of the results were the higher probability of gaining ten or more letters in BCVA with ranibizumab regimens compared with aflibercept, the greater number of injections required, and higher costs associated with aflibercept compared with ranibizumab treatment.

These results can also be explained by presence of resistance to aflibercept in a patient who was bilaterally injected. It is not known, yet, why some patients do not respond to anti-VEGF treatment or develop into non responders during the course of the treatment. Tachyphylaxis has been discussed to be important in the development of a resistance to intravitreal injections. However, the mechanisms are not clear. Genetic variants of the VEGF gene seem to alter the response to anti-VEGF treatment ${ }^{(23)}$.

As regard the effect of aflibercepton the intraocular pressure (IOP), there wasa statistically significant difference over the time after the three injections as it showed reduction in intraocular pressure especially after the first one and this may be due to the diurnal variation in IOP.
In Baek et al. (24) study of the long term effects of multiple intravitreal AntiVEGF injections on the intraocular pressure, no significant change in intraocular pressure was observed.

\section{CONCLUSION}

In this study we compared between the effect of aflibercept andranibizumab in patients with diabetic macular edema which is one of the most common complications of diabetic retinopathy. The study showed a statistically significant difference over the time through BCVA and central macular thickness with ranibizumab. There was also a statistically significant difference over the time through BCVA, central macular thickness and IOP with aflibercept. Finally, there was more improvement in BCVA which was significant and more reduction in central macular thickness with ranibizumab than with aflibercept.

\section{Recommendations}

Larger study group to confirm our results. Longer term study for the effect of ranibizumab and aflibercept injection on the central macular thickness and IOP and comparing the effect of single injection versus multiple injections. Searching for the causes of resistance or delayed response to the intravitreal injections in some patients.

\section{REFERENCES}

1. Congdon NG, Friedman DS, Lietman T (2003): Important causes of visual impairment in the world today. JAMA, 290: 60-205.

2. Korobelnik JF, Do DV, Schmidt-Erfurth U, Boyer DS, Holz FG, Heier JS et al. (2014): Intravitrealaflibercept for diabetic macular edema. Ophthalmology, 121(11):54-224.

3. Yau JW, Rogers SL, Kawasaki R, Lamoureux EL, Kowalski JW, Bek T et al. (2012): Global prevalence and major risk factors of diabetic retinopathy. Diabetes Care, 35(3): 64-556.

4. Low L, Law JP, Hodson J, McAlpine R, O'Colmain U, MacEwen C (2015): Impact of socioeconomic deprivation on the development of diabetic retinopathy: a population-based, cross-sectional and longitudinal study over 12 years. BMJ open, 5(4):e007290.

5. Miwa Y, Murakami T, Suzuma $K$ et al. (2016): Relationship between functional and structural changes in diabetic vessels in optical coherence tomography angiography. Sci Rep., 6:290.

6. Wong TY, Sun J, Kawasaki R, Ruamviboonsuk P, Gupta N, Lansingh VC, Maia M, Mathenge W, Moreker S, Muqit MM and Resnikoff $S$ (2018): Guidelines on Diabetic Eye Care: The International Council of Ophthalmology 
Recommendations for Screening, Follow-up, Referral, and Treatment Based on Resource Settings. Ophthalmology, 233-241.

7. ICO Guidelines(2017): Diabetic Eye Care, 2017. www. icoph. org/ downloads/ ICOGuidelinesforDiabeticEyeCare.

8. Varma R, Bressler NM, Doan QV et al. (2014): Prevalence and risk factors for diabetic macular edema in the United States. JAMA Ophthalmol.,40:132:134.

9. Yang XL, Liu $K$ and $X u X$ (2009): Update on treatments of diabetic macular edema. Chin Med J (Engl), 122(22): 90278.

10. Das A, McGuire PG, Rangasamy $S$ (2015): Diabetic macular edema: pathophysiology and novel therapeutic targets. Ophthalmology, 122(7):1375-94.

11. Stitt AW, Lois N, Medina RJ, Adamson $P$ and Curtis TM (2013): Advances in our understanding of diabetic retinopathy.ClinSci (Lond), 125(1):1-17.

12. Kim BY, Smith SD and Kaiser PK (2006): Optical coherence tomographic patterns of diabetic macular edema. Am J Ophthalmol., 142(3):12-405.

13. Al-latayfeh MM, Sun JK and Aiello LP (2010): Ocular Coherence Tomography and Diabetic Eye Disease. SeminOphthalmol., 25(5-6): 7-192.

14. Miller JW, Le Couter J, Strauss EC and Ferrara N (2013): Vascular endothelial growth factor a in intraocular vascular disease. Ophthalmology, 120(1):14-106.

15. Arevalo JF, Lasave AF, Wu L et al. (2013): Intravitreal bevacizumab plus grid laser photocoagulation or intravitreal bevacizumab or grid laser photocoagulation for diffuse diabetic macular edema: results of the PanAmerican Collaborative Retina Study Group at 24 months. Retina, 33:13-403.

16. Chen E, Looman M, Laouri $M$ et al. (2010): Burden of illness of diabetic macular edema: literature review. Curr Med Res Opin., 26(7): 1587-1597.

17. Bhagat $\mathbf{N}$, Grigorian RA, Tutela A, Zarbin MA (2009): Diabetic macular edema: pathogenesis and treatment. Surv Ophthalmol., 54(1):1-32.

18. Zhang X, Bao S, Hambly BD, Gillies MC (2009): Vascular endothelial growth factorA: a multifunctional molecular player in diabetic retinopathy. Int $\mathbf{J}$ Biochem Cell Biol., 41: 2368-2371.

19. Breen EC (2007): VEGF in biological control. J Cell Biochem., 102:1358-1367.

20. Schmidt-Erfurth U, Lang GE, Holz FG, Schlingemann RO, Lanzetta $P$, Massin $P$, Gerstner O, Bouazza AS, Shen $H$, Osborne A, Mitchell P (2014): Three-year outcomes of individualized ranibizumab treatment in patients with diabetic macular edema: the RESTORE extension study. Ophthalmology, 121(5):1045-53.

21. Ozturk BT, Kerimoglu H, Bozkurt B and Okudan S (2011): Comparison of intravitreal bevacizumab and ranibizumab treatment for diabetic macular edema. Journal of Ocular Pharmacology and Therapeutics, 27(4):373-7.

22. UK National Institute for Health and Care Excellence (NICE) (2014): Ranibizumab for treating diabetic macular oedema. https:// www. nice. org. uk/ guidance/ta274.

23. Abedi F, Wickremasinghe S, Richardson AJ, Makalic E, Schmidt DF, Sandhu SS et al. (2013): Variants in the VEGFA gene and treatment outcome after anti-VEGF treatment for neovascular age-related macular degeneration. Ophthalmology, 120(1):115-121.

24. Baek SU, Park IW and Suh W (2016): Long-term intraocular pressure changes after intravitreal injection of bevacizumab. Cutaneous and ocular toxicology, 35(4):310-4. 